\title{
Catalytic effect of metal nitrate salts during pyrolysis of impregnated biomass
}

\author{
Simon Eibner ${ }^{\mathrm{a}, \mathrm{b}}$, François Broust ${ }^{\mathrm{a}, *}$, Joël Blin ${ }^{\mathrm{a}, \mathrm{b}}$, Anne Julbe $^{\mathrm{c}}$ \\ ${ }^{a}$ Centre de Coopération International de Recherche Agronomique pour le Développement (Cirad), UPR BioWooEB, TA B-114/16, \\ 73 rue Jean-François Breton, 34398 Montpellier Cedex 5, France \\ ${ }^{\mathrm{b}}$ Institut International d'Ingénierie de l'Eau et de l'Environnement (2iE), Laboratoire Biomasse Energie et Biocarburants, Rue de la Science, \\ 01 BP 594 Ouagadougou 01, Burkina Faso \\ ${ }^{c}$ Institut Européen des Membranes (IEM), UMR 5635 CNRS-ENSCM-UM2, Université Montpellier 2 (CC 47), Place Eugène Bataillon, \\ 34095 Montpellier Cedex 5, France
}

\section{A B S T R A C T}

Catalytic pyrolysis is a promising way to improve bio-oil product quality. In this study, metal salts were directly impregnated in biomass to generate in situ catalysts and investigate their impact on pyrolysis products. Seven metals - $\mathrm{Ce}, \mathrm{Mn}, \mathrm{Fe}, \mathrm{Co}, \mathrm{Ni}, \mathrm{Cu}$ and $\mathrm{Zn}$ - were selected and impregnated in eucalyptus using nitrate salts. A fixed-bed reactor, pre-heated at $500^{\circ} \mathrm{C}$ and inerted with $\mathrm{N}_{2}$ flow, was used for pyrolysis. Both gas and bio-oil compositions were analysed, paying particular attention to the production of anhydrosugars. The anhydrosugar yields were found to be strongly influenced by the presence of metal salt catalysts. In particular, both $\mathrm{Zn}$ and $\mathrm{Co}$ salts yielded more anhydrosugars in comparison with catalyst-free sample. Moreover, LAC (1-hydroxy-(1R)-3,6-dioxabicyclo[3.2.1] ]octan-2-one) was produced in higher amounts than levoglucosan which is commonly produced without any catalyst. Metals were found to remain in all chars and tended to form metal-based nanoparticles (e.g. $\mathrm{Cu}^{0}, \mathrm{Ni}^{0}, \mathrm{ZnO}$ ) able to act as in situ catalysts during the pyrolysis process. It seems that those metal nanoparticles are closely related to LAC production. In parallel to metal cations, nitrates were also suspected to play a significant role during pyrolysis. The suspected impact of anions on levoglucosenone production is discussed. Concerning gas yields, the impregnated nitrate salts were found to strongly affect $\mathrm{CO}_{2}$ production.

\author{
Keywords: \\ Catalysis \\ Biomass \\ Metal \\ Nitrate \\ Anhydrosugar \\ Nanoparticle
}

\section{Introduction}

Thermochemical processes are developed to convert lignocellulosic biomass into valuable products. Pyrolysis - thermochemical degradation of organic matter under an inert atmosphere - is investigated in order to obtain bio-oils and chars. Bio-oils contain a wide range of chemicals which can be of interest or can be used as fuels. However, bio-oils are known to be unstable over time and to be very sensitive to heat. Bio-oils also suffer from a low "lower heating value" (LHV) and a high viscosity [1]. Thus, there is a consensus to say that catalysis is needed to improve the pyrolysis product quality. Transition metals are currently used as catalysts for the production of chemicals and fuels. For instance iron and cobalt are involved in the Fischer-Tropsch process although copper and zinc are rather used in methanol synthesis. Nickel catalysts are involved in hydrogenation/dehydrogenation processes.

\footnotetext{
Selected Paper from Pyrolysis 2014, Birmingham, U.K. 19-23 May 2014.

* Corresponding author. Tel.: +33467615843.

E-mail address: francois.broust@cirad.fr (F. Broust).
}

Different catalytic strategies were reported in the literature to improve the pyrolysis product quality. Most of the time, the catalysts are supported on alumino-silicate structures, like zeolites [2]. Catalysts can be mixed with the biomass within the reactor [3], or placed in a fixed-bed at the outlet of the pyrolysis reactor [4], or used as a bed material in fluidised bed reactors [5]. Pyrolysis of metal salt impregnated biomass has also been considered. In this case, the catalyst is very close to the lignocellulosic structure and is supposed to act directly on the primary reactions. This approach is another promising catalytic strategy. A lot of studies reported that metals remain in chars after pyrolysis and that those metals can be recovered after char combustion [6-8]. Thus, metal recycling from chars is easier than their recycling from alumino-silicate structures.

A large number of metal salts have been impregnated in biomass for comparing their catalytic performance. Lu et al. [9] have compared the products derived either from the pyrolysis of $\mathrm{ZnCl}_{2}$ impregnated biomass or from the pyrolysis followed by vapour catalysis with $\mathrm{ZnCl}_{2}$. Impregnation was found to favour the formation of water, furfural and anhydrosugars. Jakab et al. [10] investigated the catalytic effect of zinc acetate on 


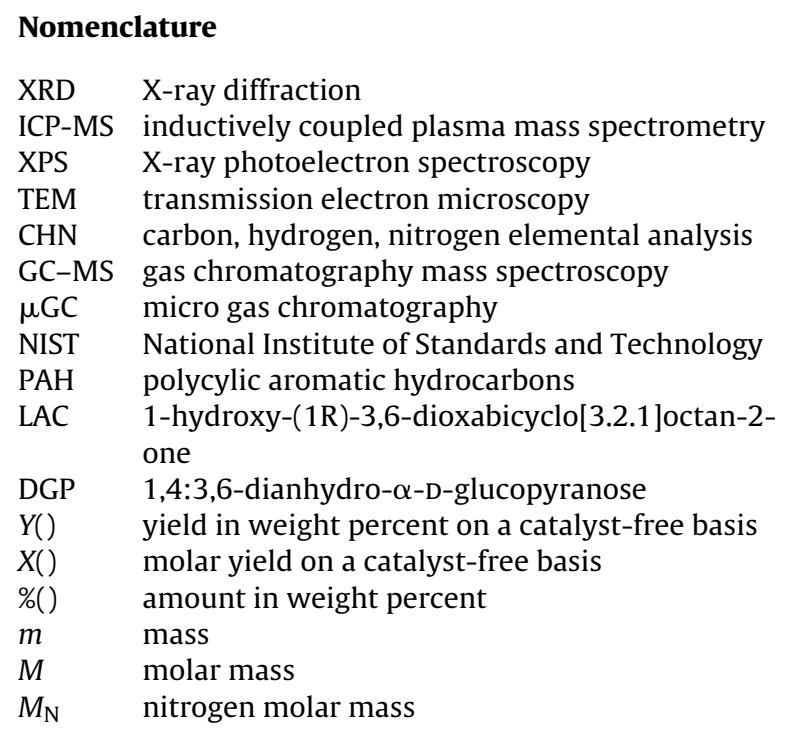

cellulose pyrolysis and found that it mainly act on anhydrosugar yields.

$\mathrm{CoCl}_{2}$ impregnation in almond shells was reported by Conesa et al. [11] for increasing furfural, $\mathrm{H}_{2}$ and water yields. On the other hand, Khelfa et al. [12] showed that impregnation of $\mathrm{MnCl}_{2}$ and $\mathrm{NiCl}_{2}$ has a negligible impact on lignin pyrolysis. Collard et al. [13] showed that impregnation of cellulose with $\mathrm{Fe}\left(\mathrm{NO}_{3}\right)_{3}$ and $\mathrm{Ni}\left(\mathrm{NO}_{3}\right)_{2}$ catalyses both water and $\mathrm{CO}_{2}$ production.

A wide variety of anions - chlorides [14,15], nitrates [16,17], hydroxides [15], carbonates [15], acetates [10,15], sulfates [17,18] and phosphates [18] - has been considered in the literature dedicated to catalytic pyrolysis. It has been shown that anions have an impact on the pyrolysis products. Indeed, Conesa et al. [11] reported the formation of chloromethane when using $\mathrm{CoCl}_{2}$. Dobele et al. [18] compared the role of $\mathrm{Fe}_{2}\left(\mathrm{SO}_{4}\right)_{3}$ and $\mathrm{Fe}^{3+}$ during cellulose pyrolysis, focusing on anhydrosugar formation. Sulfate anion seems to play the role of an acidic catalyst as it reduces levoglucosan yield while levoglucosenone - a less hydrated anhydrosugar - is favoured. Levoglucosenone was not detected in the presence of only $\mathrm{Fe}^{3+}$. Terakado et al. [17] compared the performance of $\mathrm{ZnCl}_{2}, \mathrm{Zn}\left(\mathrm{NO}_{3}\right)_{2}$ and $\mathrm{ZnSO}_{4}$ and revealed that nitrate salts were thermally degraded at lower temperature than sulfate and chloride salts. Moreover, Terakado and co-workers assumed that nitrates and sulfates evaporate as $\mathrm{NO}_{x}$ and $\mathrm{SO}_{x}$ respectively. Differences induced by the use of nitrate or sulfate salts on the primary degradation mechanisms of impregnated wood have been studied by Mayer et al. [19]. However, no explanation was given to explain this difference. Some anions can also have a poisoning effect on catalyst. For instance, it has been shown that chlorides favour copper deactivation [20] upon heating.

The objective of this study was to investigate the pyrolysis of metal salt impregnated biomass. Indeed, the catalytic effect of cations on pyrolysis products remains unclear even if it seems that they promote especially anhydrosugar and gas formation. Seven metals - cerium, manganese, iron, cobalt, nickel, copper and zinc - were screened. Nitrates were chosen both to avoid catalyst poisoning and because they are easily removed at low temperatures during pyrolysis. Impregnation was carried out under vacuum, targeting constant molar contents of metals. Comparison of the pyrolysis product species and yields helped to better understand the catalytic effect of the impregnated metal salts by mainly focusing on both anhydrosugar and gas formation. The dispersion and the oxidation state of metal active sites in chars were investigated.
Table 1

Metal nitrate salt concentrations of impregnation solutions.

\begin{tabular}{ll}
\hline & Concentration (mol/L) \\
\hline $\mathrm{Mn}\left(\mathrm{NO}_{3}\right)_{2}$ & 1.47 \\
$\mathrm{Fe}\left(\mathrm{NO}_{3}\right)_{3}$ & 1.75 \\
$\mathrm{Co}\left(\mathrm{NO}_{3}\right)_{2}$ & 1.48 \\
$\mathrm{Ni}\left(\mathrm{NO}_{3}\right)_{2}$ & 1.69 \\
$\mathrm{Cu}\left(\mathrm{NO}_{3}\right)_{2}$ & 1.20 \\
$\mathrm{Zn}\left(\mathrm{NO}_{3}\right)_{2}$ & 1.23 \\
$\mathrm{Ce}\left(\mathrm{NO}_{3}\right)_{3}$ & 1.47 \\
\hline
\end{tabular}

Finally, a specific discussion is focused on nitrate evolution during pyrolysis and on its influence on product composition.

\section{Materials and methods}

\subsection{Biomass and chemicals}

Eucalyptus was selected for this study because of its low ash content which reduces potential undesirable catalytic effects during pyrolysis. Moreover eucalyptus is a fast-growing tree whose wood is commonly used as energy feedstock [21,22]. Eucalyptus logs were purchased. Bark was removed. Logs were cut, grinded and sieved between $0.5 \mathrm{~mm}$ and $2 \mathrm{~mm}$. Biomass was dried at least for $24 \mathrm{~h}$ at $105^{\circ} \mathrm{C}$ before each experiment. The ultimate analysis of eucalyptus on a dry ash-free basis gave the following composition: C 47.9 wt.\%; 045.7 wt.\%; H 6.1 wt.\% and N 0.3 wt.\%. The oxygen content was calculated by difference.

Ammonia, nitric acid and nitrate salts $-\mathrm{Zn}\left(\mathrm{NO}_{3}\right)_{2} \cdot 6 \mathrm{H}_{2} \mathrm{O}$, $\mathrm{Co}\left(\mathrm{NO}_{3}\right)_{2} \cdot 6 \mathrm{H}_{2} \mathrm{O}, \mathrm{Fe}\left(\mathrm{NO}_{3}\right)_{3} \cdot 9 \mathrm{H}_{2} \mathrm{O}, \mathrm{Ni}\left(\mathrm{NO}_{3}\right)_{2} \cdot 6 \mathrm{H}_{2} \mathrm{O}, \mathrm{Ce}\left(\mathrm{NO}_{3}\right)_{3} \cdot 6 \mathrm{H}_{2} \mathrm{O}$, $\mathrm{Mn}\left(\mathrm{NO}_{3}\right)_{2} \cdot 4 \mathrm{H}_{2} \mathrm{O}$ and $\mathrm{Cu}\left(\mathrm{NO}_{3}\right)_{2} \cdot 3 \mathrm{H}_{2} \mathrm{O}$ - were purchased from Sigma Aldrich. Salt purity was at least $97 \%$.

\subsection{Metal salt impregnation under vacuum}

Two adsorption-impregnation methods - either at atmospheric pressure or under vacuum - have been compared in our team and published by Richardson et al. [23]. Impregnation under vacuum was selected in the present work since it was found to reduce both the required solution volume and operation duration. $38 \mathrm{~g}$ of dried biomass were immersed in $205 \mathrm{~mL}$ of nitrate solution. Some salts such as zinc and copper nitrates were more easily impregnated than iron nitrate. Thus, calibration curves were previously determined for each solution in order to target $0.65 \mathrm{mmol}$ of cations per gram of dried biomass. The corresponding concentrations of the impregnation solutions are reported in Table 1 . The $\mathrm{pH}$ was considered as a key parameter as it acts on the biomass surface charges which are closely linked to the impregnation efficiency. In addition, a too low $\mathrm{pH}$ might degrade hemicelluloses and reduces the mass of organic matter to be valorised. Finally, low pH enhances the removal of ashes in biomass [13], thus reducing at the same time undesirable catalytic effects. As a compromise, the $\mathrm{pH}$ was set at 1.9 by adding diluted nitric acid and/or ammonia. Biomass was maintained in the solution by a stainless grid, it was immersed in the salt solution during $25 \mathrm{~min}$ at $25 \mathrm{mbar}$ and then $2 \mathrm{~h}$ at atmospheric pressure. After that, biomass was filtered and washed with $205 \mathrm{~mL}$ of demineralised water to remove unadsorbed cations. Then, the impregnated biomass was dried at $105^{\circ} \mathrm{C}$ for at least $72 \mathrm{~h}$. Metal concentrations were checked by ICP-MS.

A catalyst-free sample was also prepared for comparison purposes: biomass was immersed in $205 \mathrm{~mL}$ of demineralised water whose $\mathrm{pH}$ was adjusted at 1.9. The above-described protocol was also applied to this sample. 


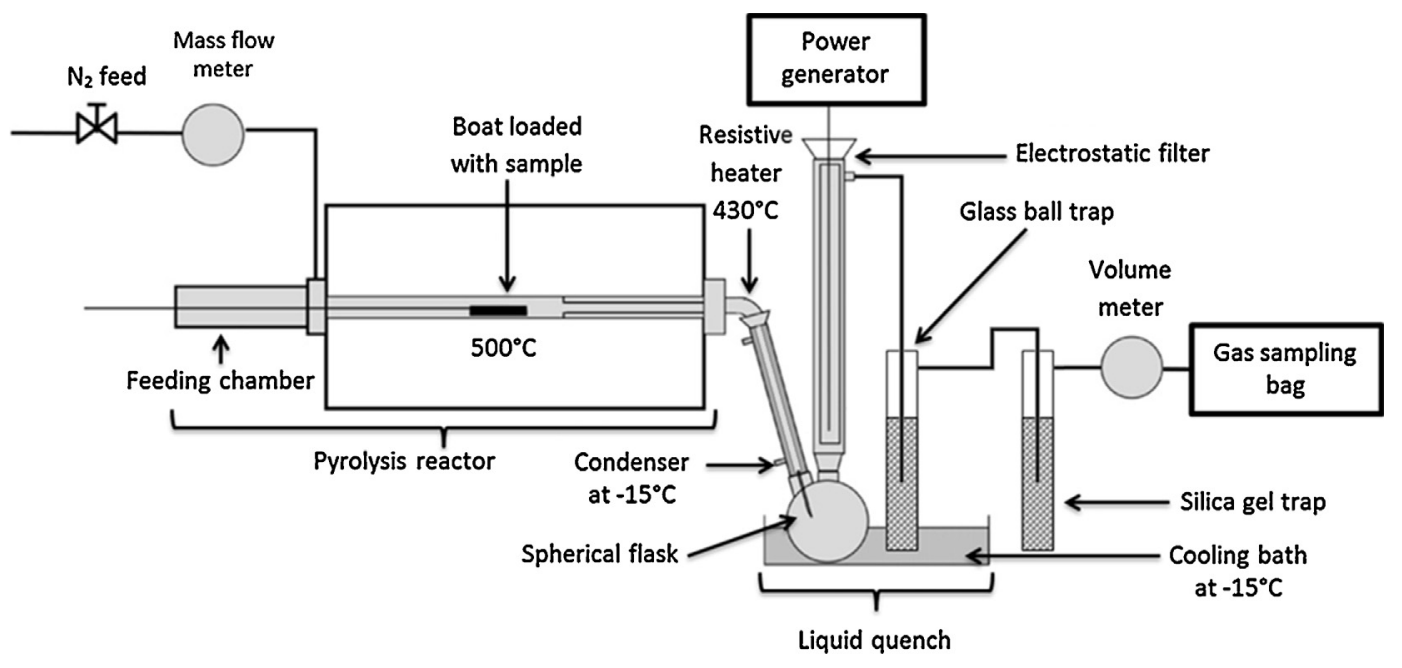

Adapted from Ref. [13].

Fig. 1. Schematic diagram of the pyrolysis reactor.

\subsection{Pyrolysis reactor}

Pyrolysis experiments were performed at $500^{\circ} \mathrm{C}$ in a tubular fixed bed reactor already described by Collard et al. [13] (Fig. 1). The carrier gas was $\mathrm{N}_{2}$ at a flow rate of $41.7 \mathrm{NL} / \mathrm{h}$. Oxygen content was lower than $0.1 \mathrm{~mol} \%$ during pyrolysis. Biomass samples, first kept in a cooled chamber during pre-heating, were inserted for $12 \mathrm{~min}$ in the reactor with a stainless steel boat (length: $8 \mathrm{~cm}$, mesh size: $200 \mu \mathrm{m}$ ) connected to a stem. A resistive heater was placed at the end of the reactor to avoid early pyrolysis vapour condensation. The condensation train was composed of a condenser linked to a spherical flask immersed in a cooling bath connected to an electrostatic filter. Bio-oils were recovered in acetone. The temperature of the coolant was $-15^{\circ} \mathrm{C}$. Both a glass ball trap and a silica gel trap were used to recover the remaining light pyrolysis vapours. The molecules adsorbed on the silica gel could not be recovered. Thus, the molecules in the glass ball trap were dissolved in acetone before GC-MS analysis and the composition was extrapolated to the silica gel trap. All the samples were stored at $4{ }^{\circ} \mathrm{C}$ in the dark in order to limit bio-oil ageing. Uncondensed gases were trapped in a sampling bag during pyrolysis and were analysed with a $\mu \mathrm{GC}$ at the end of the experiment. Chars were recovered after cooling and were placed in a flask previously inerted with nitrogen before being weighed. Pyrolysis experiments were carried out at least twice in order to calculate mean values and to insure repeatability. The error bar extremities represent the minimum and maximum measured values.

\subsection{Analysis}

\subsection{1. $\mu G C$}

After being collected in a sampling bag, gases were analysed with a $\mu \mathrm{GC}$ (Agilent Varian CP-4900). $\mathrm{N}_{2}, \mathrm{O}_{2}, \mathrm{H}_{2}, \mathrm{CO}, \mathrm{CO}_{2}, \mathrm{CH}_{4}$, $\mathrm{C}_{2} \mathrm{H}_{4}$ and $\mathrm{C}_{2} \mathrm{H}_{6}$ were analysed on two columns: Molsieve $5 \mathrm{~A}$ and Poraplot $\mathrm{Q}$. At least, five measurements were performed for each experiment in order to obtain average values. For each experiment, a good repeatability was obtained (error $<0.1 \%$ ). Gas mass could be calculated by comparison with nitrogen mass which was known.

\subsubsection{Bio-oil analysis: GC-MS and Karl-Fischer}

Bio-oils were analysed by both GC-MS and Karl-Fischer titration. The water yields in liquid samples were measured by Karl Fischer volumetric titration (Mettler Toledo). Comprehensive details on GC-MS analysis procedure have been previously published $[13,24]$. Bio-oils were recovered from the condenser in acetone. $2 \mathrm{~mL}$ samples of diluted bio-oils were filtered at $0.45 \mu \mathrm{m}$. $1 \mathrm{~mL}$ of solution was placed in a vial. $0.1 \mathrm{~mL}$ of an internal standard solution containing deuterated phenol, toluene and phenantrene - was added to the vial. Samples were analysed by gas chromatography (Agilent 6890 - GC column: DB-1701 (14\%-cyanopropyl-phenyl)-methylpolysiloxane) coupled with mass spectrum detector (Agilent 5975). Molecules were identified by comparison with the NIST database. About 70 molecules have been previously calibrated: the response factors were calculated for each of the related peaks. A solution containing known amounts of LAC and DGP, provided by the University of Bologna, was used for calibration purposes.

A typical chromatogram with labelled peaks is shown in Fig. 2. Table 2 presents a short list of the main molecules which were previously calibrated.

\subsubsection{ICP-MS and ultimate analysis}

Inductively coupled plasma mass spectroscopy and ultimate analysis were performed on the pyrolysis products to quantify their carbon, hydrogen, nitrogen and inorganic species contents.

For ICP-MS, about $500 \mathrm{mg}$ of sample were required. The sample was ground at $500 \mu \mathrm{m}$ and immersed for $3 \mathrm{~h}$ in a boiling solution of aqua regia (hydrogen chloride and nitric acid, volumetric ratio 14:5). Solutions were filtered and diluted. Amounts of inorganic species were measured by ICP-MS.

For ultimate analysis, samples were finally burned at $960^{\circ} \mathrm{C}$ in oxygen. Both $\mathrm{CO}_{2}$ and $\mathrm{H}_{2} \mathrm{O}$ were trapped on a molecular sieve and $\mathrm{NO}_{x}$ were reduced to $\mathrm{N}_{2}$ thanks to a W-based catalyst. $\mathrm{N}_{2}$ amounts were measured by a thermal conductivity detector (TCD). $\mathrm{CO}_{2}$ and $\mathrm{H}_{2} \mathrm{O}$ were alternately desorbed to be quantified.

Knowing carbon, nitrogen, hydrogen and inorganic amounts in the samples, the oxygen content was calculated by difference.

\subsubsection{Char analysis}

Chars were analysed by TEM, XRD and XPS. For TEM analyses (TEM 1200EX2,100 kV) the chars were ground and poured in a resin in order to be sliced ( $70 \mathrm{~nm}$ thick). Ground chars were also used for XRD analyses which were performed on a Philips X'Pert diffractometer using a copper radiation source $\left(E_{\mathrm{K}_{\alpha}}(\mathrm{Cu})=\right.$ $8050.9 \mathrm{eV})$. XPS analyses were carried out on $700 \mu \mathrm{m} \times 300 \mu \mathrm{m}$ surfaces, using a Kratos Axis Ultra DLD spectrometer $(8 \mathrm{~mA}$ and $15 \mathrm{kV}$ ). The monochromatic X-ray source was aluminium $\mathrm{K}_{\alpha}$ line 


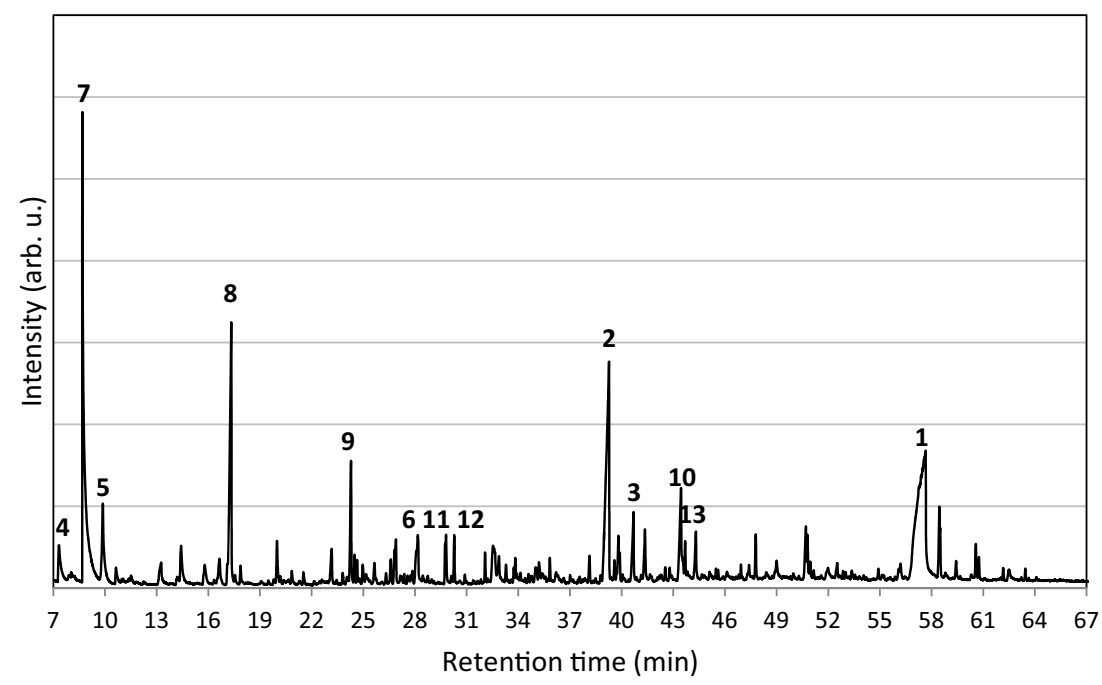

Fig. 2. Typical total ion chromatogram obtained by GC-MS analysis of the bio-oil produced from zinc salt-impregnated biomass.

$\left(E_{\mathrm{K}_{\alpha}}(\mathrm{Al})=1486.6 \mathrm{eV}\right)$ and spectra were recorded with a take-off angle of $90^{\circ}$.

\subsubsection{Expression of product yields on a "catalyst-free basis"}

In order to be able to compare the results, product yields have to be calculated on a "catalyst-free basis", which means that the mass of metals and nitrates (or nitrate derivatives) must be subtracted from the mass of impregnated biomass and related chars.

Table 2

List of the main molecules calibrated on GC-MS and associated peak number.

\begin{tabular}{|c|c|c|}
\hline Liquid organic fraction composition & $\begin{array}{l}\text { Retention time } \\
(\mathrm{min})\end{array}$ & $\begin{array}{l}\text { Peak } \\
\text { number }\end{array}$ \\
\hline \multicolumn{3}{|l|}{ Anhydrosugars } \\
\hline $\begin{array}{l}\text { 1,6-Anhydro- } \beta \text {-D-glucopyranose } \\
\text { (levoglucosan) }\end{array}$ & 57.6 & 1 \\
\hline $\begin{array}{l}\text { 1-Hydroxy, (1R)-3,6- } \\
\text { dioxabicyclo[3.2.1] octan-2-one } \\
\text { (LAC) }\end{array}$ & 39.3 & 2 \\
\hline $\begin{array}{l}\text { 1,4:3,6-Dianhydro- } \alpha-D- \\
\text { glucopyranose } \\
\text { (DGP) }\end{array}$ & 40.7 & 3 \\
\hline \multicolumn{3}{|l|}{ Aldehydes, ketones, acids and alcohols } \\
\hline Glycolaldehyde & 7.3 & 4 \\
\hline 1-Hydroxy-2-propanone & 9.9 & 5 \\
\hline 3-Methyl-1,2-cyclopentanedione & 28.2 & 6 \\
\hline Acetic acid & 8.7 & 7 \\
\hline \multicolumn{3}{|l|}{$\begin{array}{l}\text { Other aldehydes, ketones, acids and } \\
\text { alcohols }^{\mathrm{a}}\end{array}$} \\
\hline \multicolumn{3}{|l|}{ Furans } \\
\hline Furfural & 17.3 & 8 \\
\hline 5-Methylfurfural & 24.9 & 9 \\
\hline $\begin{array}{l}\text { 5-Hydroxymethylfurfural } \\
\text { Other furans }{ }^{\text {b }}\end{array}$ & 43.4 & 10 \\
\hline \multicolumn{3}{|l|}{ Phenols } \\
\hline Phenol & 29.8 & 11 \\
\hline Guaiacol (2-methoxyphenol) & 30.3 & 12 \\
\hline Syringol (2,6-dimethylphenol) & 43.7 & 13 \\
\hline \multicolumn{3}{|l|}{ Other phenols ${ }^{c}$} \\
\hline$P A H^{\mathrm{d}}$ & & \\
\hline
\end{tabular}

a Acetaldehyde, 2-cyclopenten-1-one, 3-methyl-2-cyclopenten-1-one, 1-hydroxy-butanone, formic acid, propionic acid, methanol.

b 2-Furanmethanol.

c Phenol, 2-methylphenol, 3-methylphenol, 4-methylphenol, 2,4dimethyphenol, 3,4-dimethyphenol, hydroquinone, 2-methoxy-4-methylphenol, 2-methoxy-4-ethylphenol, eugenol, isoeugenol, 2-methoxy-4-vinylphenol.

d Fluorene, naphthalene, phenantrene.
The present subsection describes the assumptions and calculations made, respectively for metals and nitrates.

Biomass samples were impregnated with the aim of inserting constant molar quantity of cations. It can be noticed that impregnation efficiency depends on the nature of the salt. Indeed, in spite of precautions taken during impregnation the iron, copper, cerium and cobalt contents in biomass measured by ICP-MS were lower than expected (Table 3). These discrepancies confirm that it is preferable to make systematic corrections, from the actual ICP-MS analyses. Additional, ICP-MS measurements (not reported) revealed that more than $95 \%$ of the metal remained in the chars after pyrolysis. Thus the mass of impregnated metal was finally deducted from both the mass of biomass and char.

High nitrogen contents - revealed by ultimate analyses - proved that nitrates were partially impregnated in biomass. However, the highest nitrate amounts were detected in biomass impregnated with trivalent salts - iron and cerium - while very low nitrate amount was impregnated in the copper-based sample. Interestingly, elemental analyses also revealed higher nitrogen amounts in impregnated chars in comparison with metal-free samples, which can be attributed to the presence of nitrate-derivatives in char. However, their actual form is not exactly known. The thermal degradation of metal nitrates in inert atmosphere has been broadly studied in the literature [25-31] and it was found that nitrates were removed as $\mathrm{NO}_{x}$ between 150 and $300^{\circ} \mathrm{C}$. Similarly to the thermal decomposition of nitrocellulose - cellulose doped with nitric acid - it might be assumed that those $\mathrm{NO}_{x}$ are mainly $\mathrm{NO}_{2}$ [32]. Since carbon-based materials are efficient adsorbents [33], the extra-nitrogen measured in chars might therefore originate from the partial adsorption of $\mathrm{NO}_{2}$ on the carbonaceous material [34] (Table 3). This assumption will be further discussed in Section 4.3.

Based on elemental analyses, the amount of impregnated nitrates and adsorbed $\mathrm{NO}_{2}$ were calculated as follows (cf. Nomenclature):

$\%\left(\mathrm{NO}_{3 \text { bio }}\right)=\left(\%\left(\mathrm{~N}_{\text {bio }}\right)-\%\left(\mathrm{~N}_{\text {cata-free bio }}\right)\right) \times \frac{M_{\mathrm{NO}_{3}}}{M_{\mathrm{N}}}$
$\%\left(\mathrm{NO}_{2 \text { ads }}\right)=\left(\%\left(\mathrm{~N}_{\text {char }}\right)-\%\left(\mathrm{~N}_{\text {cata-free char }}\right)\right) \times \frac{M_{\mathrm{NO}_{2}}}{M_{\mathrm{N}}}$

Finally, product yields were calculated on a catalyst-free basis as follows:

$Y($ gas $)=\frac{m_{\text {gas }}}{m_{\text {bio }} \times\left[1-\%\left(\mathrm{NO}_{3 \text { bio }}\right)-\%\left(\text { cation }_{\text {bio }}\right)\right]}$ 
Table 3

Metal content in biomass. Nitrogen amounts (wt.\%) in both biomass and chars and their related amounts (wt.\%) of nitrates and adsorbed nitrogen dioxide.

\begin{tabular}{|c|c|c|c|c|c|c|}
\hline \multirow[b]{2}{*}{ Metal } & \multicolumn{4}{|l|}{ Biomass } & \multicolumn{2}{|l|}{ Char } \\
\hline & Cation $_{\text {bio }}(\mathrm{mmol} / \mathrm{g})^{\mathrm{a}}$ & $\%\left(\right.$ Cation $\left._{\text {bio }}\right)(\text { wt.\% })^{a}$ & $\%\left(\mathrm{~N}_{\text {bio }}\right)(\mathrm{wt} . \%)^{\mathrm{a}}$ & $\%\left(\mathrm{NO}_{3 \text { bio }}\right)(\text { wt. } \%)^{\mathrm{b}}$ & $\%\left(\mathrm{~N}_{\text {char }}\right)(\mathrm{wt} . \%)^{\mathrm{a}}$ & $\%\left(\mathrm{NO}_{2}\right.$ ads $)(\mathrm{wt} . \%)^{\mathrm{b}}$ \\
\hline Catalyst-free & - & - & 0.15 & - & 0.15 & - \\
\hline Cerium & 0.51 & 7.15 & 1.60 & 6.46 & 0.47 & 1.05 \\
\hline Cobalt & 0.53 & 3.12 & 0.84 & 3.07 & 0.40 & 0.83 \\
\hline Copper & 0.47 & 2.99 & 0.37 & 1.00 & 0.32 & 0.57 \\
\hline Iron & 0.46 & 2.57 & 1.67 & 6.74 & 1.03 & 2.89 \\
\hline Manganese & 0.74 & 4.07 & 1.51 & 6.03 & 0.57 & 1.38 \\
\hline Nickel & 0.68 & 3.99 & 1.20 & 4.67 & 0.52 & 1.23 \\
\hline Zinc & 0.59 & 3.86 & 0.84 & 3.09 & 0.48 & 1.08 \\
\hline
\end{tabular}

a Measured by elemental analysis.

b Calculated.

$Y($ organic fraction $)=\frac{m_{\text {organicfraction }}}{m_{\text {bio }} \times\left[1-\%\left(\mathrm{NO}_{3 \text { bio }}\right)-\%\left(\text { cation }_{\text {bio }}\right)\right]}$

$Y($ water $)=\frac{m_{\text {water }}}{m_{\text {bio }} \times\left[1-\%\left(\mathrm{NO}_{3 \text { bio }}\right)-\%\left(\text { cation }_{\text {bio }}\right)\right]}$

$Y($ chars $)=\frac{m_{\text {char }} \times\left[1-\%\left(\mathrm{NO}_{2 \text { ads }}\right)\right]}{m_{\text {bio }} \times\left[1-\%\left(\mathrm{NO}_{3 \text { bio }}\right)-\%\left(\text { cation }_{\text {bio }}\right)\right]}$

The molar yields of each chemical species “a” - referring to $\mathrm{CO}_{2}$, $\mathrm{CO}, \mathrm{H}_{2}, \mathrm{CH}_{4}, \mathrm{C}_{2} \mathrm{H}_{4}$ or $\mathrm{C}_{2} \mathrm{H}_{6}$ - were calculated, on a catalyst-free basis, as follows:

$X(\mathrm{a})=\frac{m_{\mathrm{a}}}{m_{\text {bio }} \times\left[1-\%\left(\mathrm{NO}_{3 \text { bio }}\right)-\%\left(\text { cation }_{\text {bio }}\right)\right]} \times \frac{1}{M_{\mathrm{a}}}$

\section{Results}

\subsection{Pyrolysis products derived from metal nitrate impregnated} biomass

In this section, pyrolysis yields are presented and expressed on a "catalyst-free basis". As far as nitrate salts were supposed to catalyse mainly anhydrosugar and gas formation, the corresponding yields were thus discussed in more details.

\subsubsection{Pyrolysis yields from impregnated biomass}

Product yields - calculated on a "catalyst-free basis" - are reported in Fig. 3. Mass closure was higher than 94\% for all experiments, thus confirming that major part of pyrolysis products was recovered. Metals were found to enhance char formation: by $+20 \%$ on average, in comparison with a catalyst-free sample. Char yields were higher with cerium, manganese and zinc in comparison with nickel and copper. It was also noted that gas formation was significantly increased with metals: gas yield increased from $+25 \%$ for $\mathrm{Zn}$-sample, up to $+55 \%$ for Ni-sample, in comparison with a catalyst-free sample. Interestingly, the lowest organic fraction yield and highest gas yield were obtained with nickel. This demonstrated that nickel is an active catalyst for cracking reactions. Water production was only slightly favoured by metals except in the case of copper (yielding a slightly lower water content).

\subsubsection{Catalytic effects of metal salts on bio-oil compositions}

Bio-oils are complex mixtures of organic molecules and water. 70 organic species - such as anhydrosugars, acids, furans, ketones, alcohols and phenol derivatives - were quantified in bio-oils; they represent more than $40 \%$ of water-free bio-oil, in agreement with typical bio-oil analysis [35]. High yields of anhydrosugars, acids, furans, aldehydes and ketons were obtained whereas few phenol derivatives - phenols, guaiacols and syringols - were detected. Metals were found to have a huge catalytic effect on anhydrosugar yields.

Levoglucosan, LAC, DGP and levoglucosenone are the most classically reported anhydrosugars [36-38] (Fig. 4). LAC - which is not in the NIST list - was identified by using the spectra published by Fabbri et al. [38].

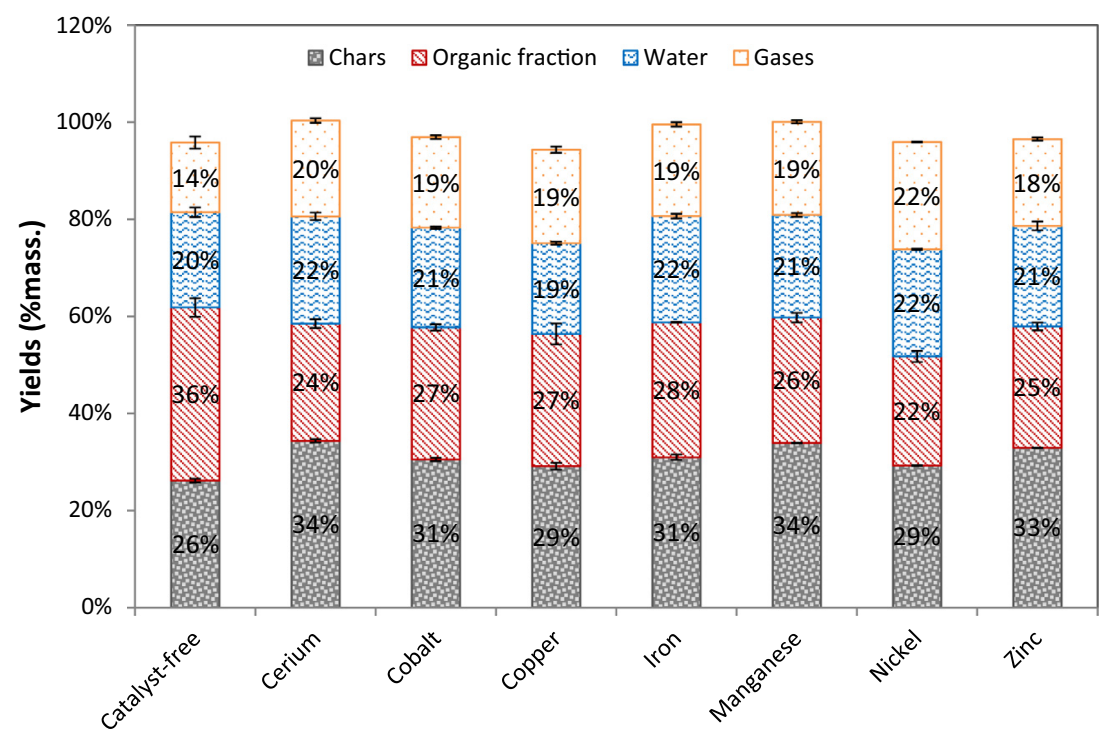

Fig. 3. Comparison of pyrolysis product yields for a series of catalyst-impregnated biomass, in comparison with a catalyst-free sample. The error bar extremities represent the minimum and maximum values. Yields are mean values. 
<smiles>O[C@@H]1[C@H](O)O[C@@H]2CO[C@H]2[C@@H]1O</smiles>

Levoglucosan<smiles>OC1C2COC(O2)C1O</smiles>

DGP<smiles>O=C1OCC2COC1(O)C2</smiles>

LAC<smiles>O=C1C=C[C@H]2CO[C@H]1O2</smiles>

Levoglucosenone

Fig. 4. From left to right: levoglucosan, 1,4:3,6-dianhydro- $\alpha$-D-glucopyranose (DGP), 1-hydroxy-(1R)-3,6-dioxabicyclo[3.2.1 ]octan-2-one (LAC) and levoglucosenone. Adapted from Ref. [39].

High levoglucosan yield was obtained in the bio-oil derived from catalyst-free biomass (Fig. 5). Iron, zinc, cobalt, cerium, nickel and manganese were found to inhibit levoglucosan formation decrease by $54 \%$ on average in comparison with a catalyst-free sample - while copper had no effect. LAC was highly favoured by zinc, cobalt, manganese, nickel, cerium and, to a lesser degree, iron. Very few LAC was produced with copper. Those results fit those of Furneaux et al. [36] who reported that LAC was catalytically produced by soaking cellulose with $\mathrm{MnCl}_{2}, \mathrm{FeCl}_{3}, \mathrm{CoCl}_{2}, \mathrm{NiCl}_{2}$ and $\mathrm{ZnCl}_{2}$ while it was not formed with $\mathrm{CuCl}_{2}$. This point will be discussed in Section 3.2.1. High LAC yield was also obtained by Jakab et al. [10] from zinc acetate impregnated cellulose, thus confirming the key role of the cation for enhancing LAC formation. Three times more DGP was produced in the presence of copper and zinc in comparison with catalyst-free samples. It has to be noticed that levoglucosenone was not detected in bio-oils, the possible reasons will be discussed in Section 4.4.

The highest yields of monomeric anhydrosugars were obtained with $\mathrm{Zn}\left(\mathrm{NO}_{3}\right)_{2}$ and $\mathrm{Co}\left(\mathrm{NO}_{3}\right)_{2}$. Thus, these salts seemed to be very efficient towards cellulose depolymerisation. On the contrary, depolymerisation seemed to be inhibited by $\mathrm{Fe}\left(\mathrm{NO}_{3}\right)_{3}$. The observed changes in LAC quantity - which contain an unusual lactone group - suggested that depolymerisation occurred differently in the presence of zinc, cobalt, nickel, manganese and cerium.

Impregnated nitrate salts have very low impact on acid and furan yields. In spite of high peak intensity (Fig. 2), furfural yields remain quite low - about $0.5 \mathrm{wt}$.\% on a catalyst-free basis - whatever the catalyst. At first sight, this result does not fit those of Di Blasi et al. [39] reporting a high catalytic effect of $\mathrm{ZnCl}_{2}$ towards furfural formation from impregnated fir wood. This difference might be explained by the chemical differences between hemicelluloses from softwood and from hardwood and by the fact that a too high $\mathrm{ZnCl}_{2}$ amount can reduce the catalytic effect [14,39].

\subsubsection{Gas yields}

All the tested metal catalysts were found to favour gas formation (Fig. 3). Gas yields reported in Fig. 6 are given on a molar basis in order to help the comparison of light gas yields. It has to be noticed that $\mathrm{CO}_{2}$ yields roughly doubled in the presence of all catalysts, especially with manganese, nickel and cerium. This important result fits those of Collard et al. [13] who obtained a similar increase by impregnating $\mathrm{Fe}\left(\mathrm{NO}_{3}\right)_{3}$ and $\mathrm{Ni}\left(\mathrm{NO}_{3}\right)_{2}$ in biomass constituents at $600{ }^{\circ} \mathrm{C}$. Surprisingly, $\mathrm{ZnCl}_{2}$ and $\mathrm{CoCl}_{2}$ salts were found to reduce $\mathrm{CO}_{2}$ formation $[7,14]$, thus suggesting that nitrates and chlorides play different roles on $\mathrm{CO}_{2}$ formation. This will be discussed in Section 4.2.

Hydrogen yields were strongly enhanced by transition metals whereas very low amount of $\mathrm{H}_{2}$ was produced with cerium. Whatever the considered transition metals, an increase of $\mathrm{H}_{2}$ yield was associated to an increase of $\mathrm{CO}$ yield. Nickel was found to be the most efficient catalyst for producing both $\mathrm{CO}$ and $\mathrm{H}_{2}$. This fits the results of Richardson et al. [6] who selected nickel to favour syngas formation. Whatever the selected catalyst, methane formation was found to slightly decrease in the presence of a catalyst.

\subsection{Nanoparticle formation in chars}

Metals - which have a catalytic effect on the formation of pyrolysis products - remain in chars after pyrolysis. Thus, TEM, XPS and XRD analyses were carried out on those chars to better understand their catalytic role during pyrolysis.

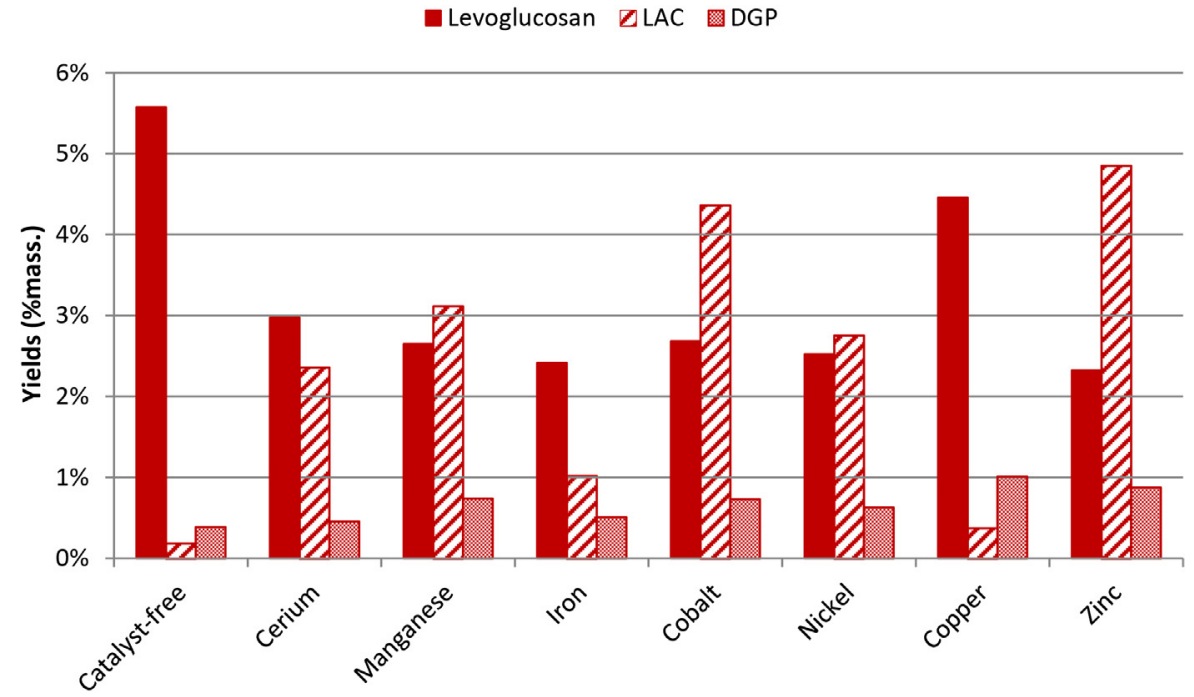

Fig. 5. Comparison of levoglucosan, LAC and DGP yields (catalyst-free basis) for a series of catalyst-impregnated biomass, in comparison with a catalyst-free sample. 


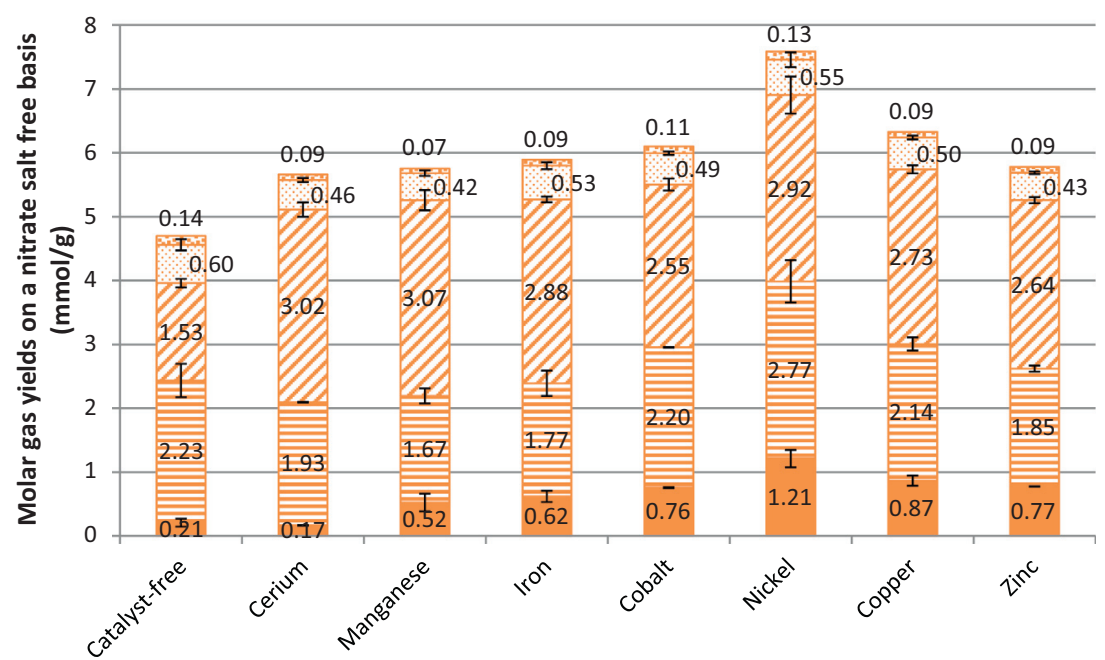

Fig. 6. Comparison of gas fraction compositions (gas molar yields) for a series of catalyst-impregnated biomass, in comparison with a catalyst-free sample. The error bar extremities represent the minimum and maximum values. Yields are mean values.

\subsubsection{Presence of nanoparticles in chars}

Nanoparticles were detected by TEM in all the chars derived from catalyst-impregnated biomass. Micrographs of chars containing nickel-, cerium- and copper-based nanoparticles are shown in Figs. 7-9 respectively. Nickel nanoparticles (Fig. 7) were very well dispersed in the char although cerium-based nanoparticles (Fig. 8) were not so uniformly distributed within the char matrix.

Very tiny nanoparticles were formed in all chars at $500^{\circ} \mathrm{C}$. Their mean diameters, measured on TEM micrographs, were close to $5 \mathrm{~nm}$ for cerium, cobalt, iron, manganese, nickel and zinc (Table 4). Similar dimensions were reported by Richardson et al. [6] for nickel nanoparticles obtained at $500^{\circ} \mathrm{C}$. In the case of copper, a large particle size distribution was observed, ranging from $5 \mathrm{~nm}$ to $65 \mathrm{~nm}$. The larger particles were formed by aggregation of small ones (doted circle in Fig. 9), in accordance with Twigg and Spencer [20] who claimed that copper more likely than iron, nickel and cobalt tends to aggregate when heated.

From a catalytic point of view, both the dispersion and size of active sites are key parameters. As copper nanoparticles were found to be sensitive to aggregation, a lower catalytic activity was expected for copper. Interestingly, copper was the only catalyst which did not enhance LAC formation. Thus, the low activity of

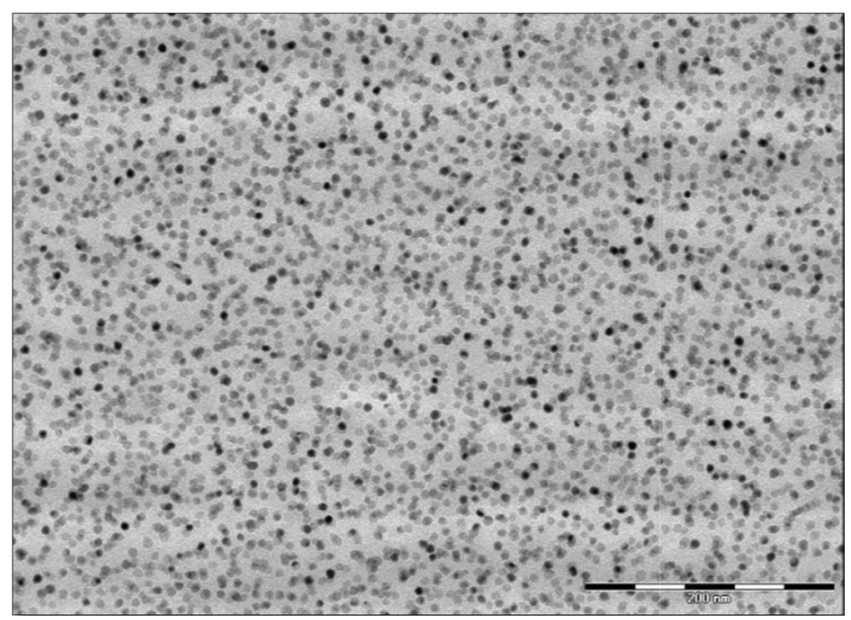

Fig. 7. TEM observation of nickel-based nanoparticles in char derived from biomass pyrolysis at $500^{\circ} \mathrm{C}$ (full scale bar: $200 \mathrm{~nm}$ ).

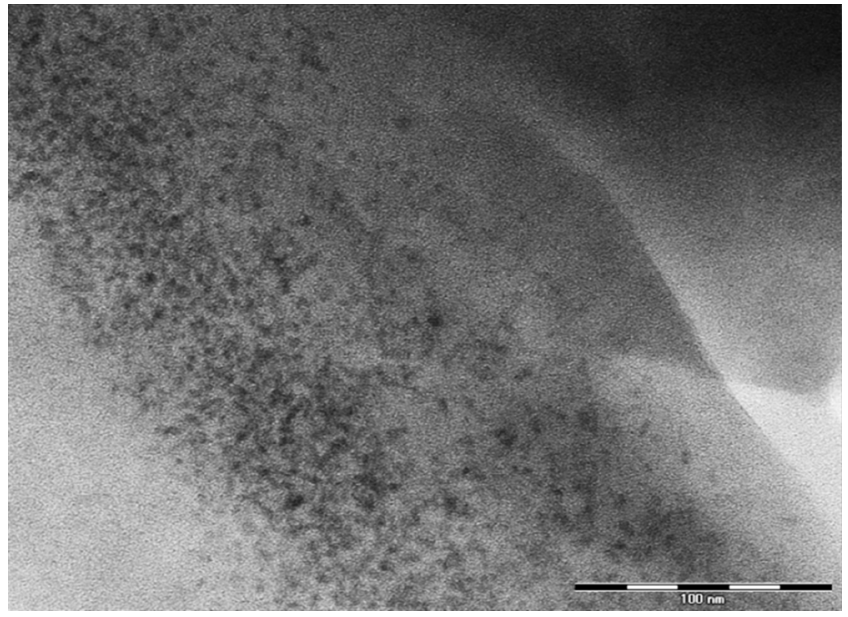

Fig. 8. TEM observation of cerium-based nanoparticles in char derived from biomass pyrolysis at $500^{\circ} \mathrm{C}$ (full scale bar: $100 \mathrm{~nm}$ ).

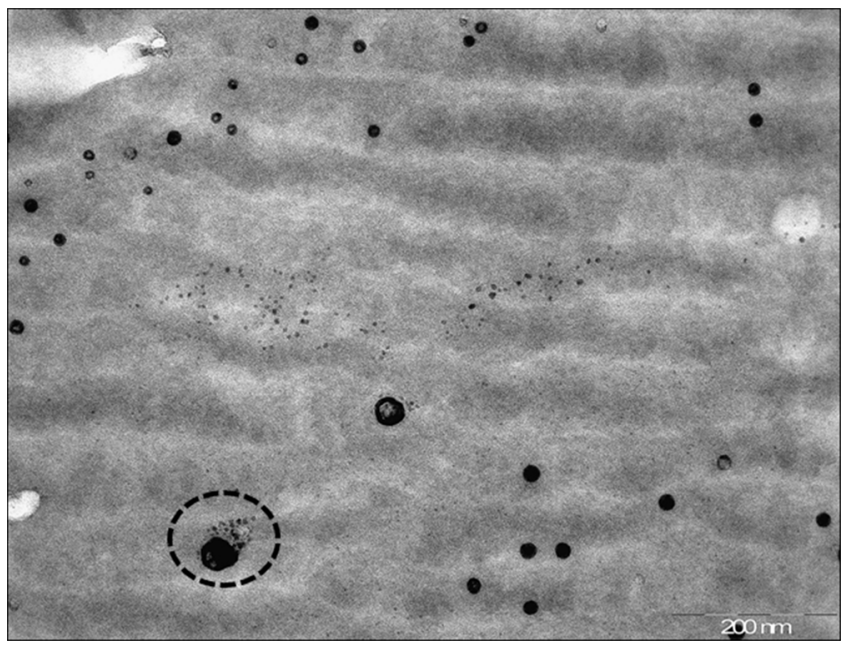

Fig. 9. TEM observation of copper nanoparticles in char derived from biomass pyrolysis at $500^{\circ} \mathrm{C}$. The doted circle evidences an agglomeration of nanoparticles (full scale bar: $200 \mathrm{~nm}$ ). 
Table 4

Mean diameter of metal-based nanoparticles measured directly on TEM micrographs.

\begin{tabular}{|c|c|c|c|c|c|c|c|}
\hline Metal & Cerium & Cobalt & Copper & Iron & Manganese & Nickel & Zinc \\
\hline Mean diameter of nanoparticles (nm) & 4.1 & 6.5 & {$[5-65]$} & 4.5 & 5.6 & 6.2 & 4.5 \\
\hline
\end{tabular}

copper catalyst towards LAC formation might be explained by its rapid deactivation - by aggregation - during pyrolysis. It confirms the results obtained by Fabbri et al. [38] who emphasised that the nanosized characteristics are a key parameter to promote LAC production.

\subsubsection{Metal oxidation state}

Knowing the oxidation states of the catalytically active sites is of great importance to better understand the catalytic activity of the formed metal-based nanoparticles. Thus, both XRD and XPS were carried out in chars recovered after pyrolysis.

Crystallites were clearly detected by XRD in nickel and copperbased chars (Fig. 10), although no XRD signal was detected with others metals. We concluded that the nanoparticles observed in the cerium, manganese, iron, cobalt and zinc-based samples were amorphous. Both copper and nickel nanoparticles were in a metallic state $\left(\mathrm{Cu}^{0}\right.$ and $\left.\mathrm{Ni}^{0}\right)$. Those results are in good accordance with those obtained by Terakado et al. [17] who showed that mixture of nickel and copper nitrate salt with wood leads to the formation of metallic nickel and copper nanoparticles. Richardson et al. [6] have shown that $\mathrm{Ni}\left(\mathrm{NO}_{3}\right)_{2}$ was first thermally degraded to $\mathrm{NiO}$. Then the char might act as a reducing agent and lead to the reduction of $\mathrm{NiO}$ to $\mathrm{Ni}^{0}$ between $400^{\circ} \mathrm{C}$ and $500^{\circ} \mathrm{C}$. It is likely that $\mathrm{Cu}^{0}$ nanoparticles were formed in the same way. $\mathrm{H}_{2}$ and $\mathrm{CO}$ - produced in large quantity with both copper and nickel - might strengthen the reduction process.

XPS analyses have been performed on all the chars. XPS spectrum of the zinc-derived char is presented in Fig. 11. Very low XPS signal intensities were observed with chars containing cerium, manganese, iron, nickel, copper and cobalt. XPS analysis only provided information on the oxidation states of metals which were at the char surface. Thus, low XPS signal intensities might be due to the partial overlaying of metal by carbon deposit for mentioned chars. XPS spectrum of zinc derived chars (Fig. 11) fitted those obtained by Marrani et al. [40] and confirmed the presence of $\mathrm{ZnO}$ on the char surface. Thus, zinc oxidation state is still $\mathrm{Zn}(\mathrm{II})$, revealing that char reduction effect did not occur in this case.

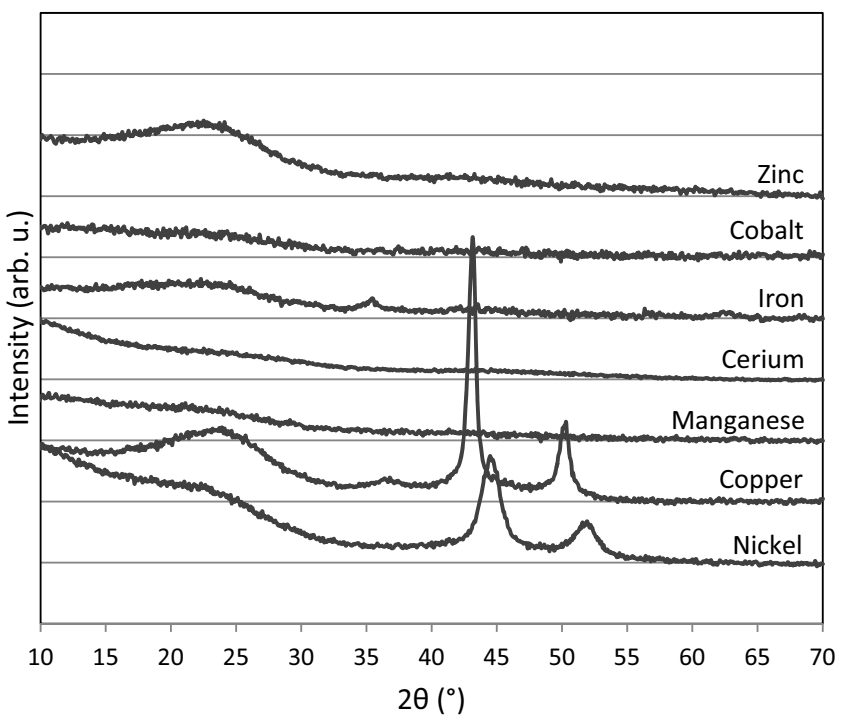

Fig. 10. Comparison of XRD patterns for chars containing metals.
Table 5

Gaseous $\mathrm{NO}_{2}$ yields resulting from the pyrolysis of a series of nitrate metal saltimpregnated biomass, in comparison with a catalyst-free sample.

\begin{tabular}{ll}
\hline Metal-based catalyst & $Y\left(\mathrm{NO}_{2 \text { (gas) }}\right)($ wt.\%) \\
\hline Catalyst-free & - \\
Cerium & 3.74 \\
Cobalt & 1.45 \\
Copper & 0.17 \\
Iron & 2.11 \\
Manganese & 3.09 \\
Nickel & 2.24 \\
Zinc & 1.21 \\
\hline
\end{tabular}

It was not possible to determine the oxidation states of metals such as cerium, manganese, iron and cobalt in chars. However, regarding others works on the thermal degradation of metal nitrate salts in oxygen-free atmospheres, it might be considered that nanoparticles of $\mathrm{CeO}_{2}$ [25], $\mathrm{MnO}_{2}$ [31], $\mathrm{Fe}_{2} \mathrm{O}_{3}$ [30] and $\mathrm{Co}_{3} \mathrm{O}_{4}$ [27] were formed in chars. However, possible reduction of those oxides by chars was likely.

\section{Discussion}

It is well-known that cations have a catalytic effect on pyrolysis products, however anions were also suspected to play a role during pyrolysis. This section investigates nitrate behaviour and their potential role on $\mathrm{CO}_{2}$ and levoglucosenone formation. The choice of an effective catalyst able to enhance LAC formation is also discussed.

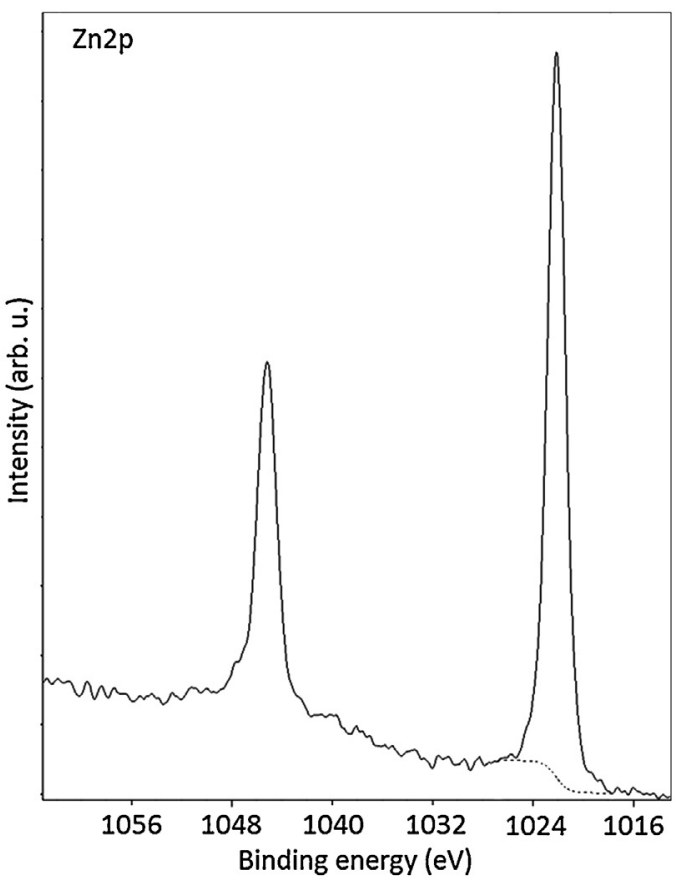

Fig. 11. XPS spectrum of the zinc-derived char. 
Table 6

Estimated ratios of exogenous $\mathrm{CO}_{2}$ resulting from the pyrolysis of a series of nitrate metal salt-impregnated biomass, in comparison with a catalyst-free sample.

\begin{tabular}{llllllll}
\hline Metal-based catalyst & Catalyst-free & Cerium & Manganese & Iron & Cobalt & Nickel & Copper \\
\hline$\frac{Y\left(\mathrm{CO}_{2 \text { exogenous }}\right)}{Y\left(\mathrm{CO}_{2 \text { total }}\right)}(\%)$ & - & 15.0 & 11.6 & 8.6 & 6.4 & 8.3 \\
\hline
\end{tabular}

\section{1. $\mathrm{NO}_{2}$ formation from nitrates during pyrolysis}

The high nitrogen amounts detected in chars were supposed to correspond to adsorbed $\mathrm{NO}_{2}$ (Table 3). However, the low amount of adsorbed $\mathrm{NO}_{2}$ in comparison with the nitrate content in biomass suggested that gaseous $\mathrm{NO}_{2}$ or other nitrogen-containing species were produced. As molecules containing nitrogen such as pyridine were not detected in bio-oils, it was assumed that gaseous $\mathrm{NO}_{2}$ was released during pyrolysis. Gaseous $\mathrm{NO}_{2}$ yields were calculated using Eq. (8). Results are reported in Table 5.

$Y\left(\mathrm{NO}_{2 \text { gas }}\right)=\left[\%\left(\mathrm{NO}_{3 \text { biomass }}\right) \times \frac{M_{\mathrm{NO}_{2}}}{M_{\mathrm{NO}_{3}}}\right]-\%\left(\mathrm{NO}_{2}\right.$ ads $)$

Very small amount of gaseous $\mathrm{NO}_{2}$ was produced during pyrolysis of copper impregnated biomass and the highest $\mathrm{NO}_{2}$ amounts were released from cerium and manganese-samples. The ironchars were found to adsorb the highest quantity of $\mathrm{NO}_{2}$.

\subsection{Exogenous $\mathrm{CO}_{2}$ formation}

Gaseous $\mathrm{NO}_{2}$ is known to be a strong oxidant. As a consequence, exogenous $\mathrm{CO}_{2}$ might be formed through direct carbon oxidation already at $300^{\circ} \mathrm{C}$, as described by Jeguirim et al. [34,41] (Eq. (9)).

$\mathrm{C}+2 \mathrm{NO}_{2} \rightarrow \mathrm{CO}_{2}+2 \mathrm{NO}$

In order to estimate the exogenous $\mathrm{CO}_{2}$ yields, gaseous $\mathrm{NO}_{2}$ was supposed to be totally converted to $\mathrm{CO}_{2}$ (Eq. (10)). The estimated ratios of exogenous $\mathrm{CO}_{2}$ are reported in Table 6.

$Y\left(\mathrm{CO}_{2 \text { exogenous }}\right)=\frac{Y\left(\mathrm{NO}_{2 \text { gas }}\right)}{2} \times \frac{M_{\mathrm{CO}_{2}}}{M_{\mathrm{NO}_{2}}}$

Those results demonstrate that nitrate degradation during pyrolysis might impact on $\mathrm{CO}_{2}$ yields. Hence, $\mathrm{CO}_{2}$ yields were probably slightly overestimated specifically for cerium, manganese, iron, nickel and to a lesser extent for cobalt and zinc. The $\mathrm{CO}_{2}$ yield for copper was not altered because of the very low nitrate amount in the biomass. Although nitrates can be removed at lower temperatures than other anions, the use of nitrate salts probably affect gas yields.

\section{3. $\mathrm{NO}_{2}$ adsorption on chars}

Ultimate analysis of chars revealed that chars derived from impregnated biomass contained more nitrogen than catalyst-free samples. Similar results were obtained by Terakado et al. [17] when operating thermal degradation of metal nitrates doped biomass. Although the formation of gaseous $\mathrm{NO}_{2}$ during nitrate thermal degradation is well documented [17,32], little is known about the nitrogen species retained in chars at high temperatures. As far as carbonaceous matrixes are efficient adsorbents [33], it can be assumed that extra-nitrogen in chars is due to $\mathrm{NO}_{2}$ adsorption. Although it has been shown that physisorbed $\mathrm{NO}_{2}$ in chars was released at $110^{\circ} \mathrm{C}$ [34], Zawadzki et al. [42] demonstrated that $\mathrm{NO}_{2}$ can be also chemisorbed on char surface and form different adsorbed species. Interestingly, although some species might desorb at $300^{\circ} \mathrm{C}$, others are very stable and might remain in chars at $500^{\circ} \mathrm{C}$. However, all the adsorbed species should decompose completely at $600^{\circ} \mathrm{C}$. Further work is needed to confirm these hypotheses.

\subsection{Suspected role of anion on levoglucosenone formation}

As reported in Section 3.1.2, levoglucosenone (anhydrosugar) was never detected in the bio-oils produced in this work. We can thus conclude that the nitrate salts (such as $\mathrm{Fe}\left(\mathrm{NO}_{3}\right)_{3}$ or $\mathrm{Zn}\left(\mathrm{NO}_{3}\right)_{2}$ ) do not catalyse its production. However, levoglucosenone formation was reported by Branca et al. [14], Klampfl et al. [43] and Dobele et al. [18] when using $\mathrm{ZnCl}_{2}, \mathrm{FeCl}_{3}$ and $\mathrm{Fe}_{2}\left(\mathrm{SO}_{4}\right)_{3}$ catalysts, respectively. This reveals that anions seem to play a major role in the formation of levoglucosenone. It is generally assumed that the thermal depolymerisation of cellulose yields anhydrosugars between $300^{\circ} \mathrm{C}$ and $390^{\circ} \mathrm{C}$ [44]. Interestingly, nitrates are removed just before reaching this temperature while sulfate or chloride remain in biomass until $400^{\circ} \mathrm{C}$ at least [17]. This could explain the role of both chlorides and sulfates towards levoglucosenone formation whereas nitrates are released before cellulose depolymerisation.

\subsection{Selection of a relevant catalyst to enhance LAC formation}

LAC (1-hydroxy-(1R)-3,6-dioxabicyclo[3.2.1]octan-2-one) was first identified in bio-oils derived from metal chloride impregnated cellulose [36]. Two decades later, LAC was also obtained from cellulose mixed with aluminium titanate nanopowders [38]. The nanosized characteristic of the catalyst was pointed out as a key factor to enhance its production. In the present work, analyses performed on chars confirmed the tendency of impregnated salts to form nanoparticles during pyrolysis, thus giving a possible way to understand and favour the production of LAC. Among the tested salts, zinc nitrate seemed to be the most active catalyst towards LAC formation. The highest catalytic activity of zinc acetate compared to calcium acetate has already been reported by Jakab et al. [10]. We should also emphasise that the selected catalyst should not deactivate at elevated temperature. Unfortunately the deactivation temperatures can hardly be determined for metal impregnated biomass. Although nitrate, chloride and acetate salts were found to favour LAC production $[10,36]$ further work is needed to compare these salts in terms of catalytic activity and stability.

\section{Conclusions}

The objective of this study was to investigate the catalytic effect of salts impregnated in biomass paying attention to the potential role of nitrates on pyrolysis products. Seven salts $-\mathrm{Ce}\left(\mathrm{NO}_{3}\right)_{3}$, $\mathrm{Mn}\left(\mathrm{NO}_{3}\right)_{2}, \mathrm{Fe}\left(\mathrm{NO}_{3}\right)_{3}, \mathrm{Co}\left(\mathrm{NO}_{3}\right)_{2}, \mathrm{Ni}\left(\mathrm{NO}_{3}\right)_{2}, \mathrm{Cu}\left(\mathrm{NO}_{3}\right)_{2}$ and $\mathrm{Zn}\left(\mathrm{NO}_{3}\right)_{2}$ - were successfully impregnated under vacuum to obtain constant molar amounts of cations. Impregnated biomass were pyrolysed under similar operating conditions. Mass balance closures were higher than $94 \%$.

Huge changes were measured on anhydrosugar yields in biooils, depending on the selected catalyst: LAC production decreased in the following order: $\mathrm{Zn}>\mathrm{Co}>\mathrm{Ni}, \mathrm{Mn}>\mathrm{Ce}>\mathrm{Fe}$. However, only small LAC amounts were produced from copper impregnated biomass. TEM observations were performed on chars to explain the low activity of copper catalyst towards LAC formation. It was found that metal nanoparticles were formed in all the chars but that copper ones deactivate by aggregation.

Nitrate evolution during pyrolysis was investigated. Both the impregnated biomass and the derived chars were found to contain extra nitrogen due to nitrate impregnation. High nitrogen amounts 
in chars suggested that $\mathrm{NO}_{2}$, resulting from the thermal degradation of nitrates, was released and partially chemisorbed on chars even at elevated temperatures. A huge increase of $\mathrm{CO}_{2}$ formation was evidenced for all catalysts compared to catalyst-free samples. Although gaseous $\mathrm{NO}_{2}$ - which is a strong oxidant - might contribute to exogenous $\mathrm{CO}_{2}$ formation even at $300^{\circ} \mathrm{C}$, only less than $15 \%$ of $\mathrm{CO}_{2}$ was found to be exogenous.

To conclude, metal nitrate salts might be impregnated in biomass to control both anhydrosugar and $\mathrm{CO}_{2}$ formation. Zinc and cobalt can be used to enhance LAC production while manganese, nickel and cerium are more suitable to catalyse $\mathrm{CO}_{2}$ formation which might be a recommended pathway to promote de-oxygenation of bio-oils. More attention has to be paid on the possible impacts of anion during pyrolysis.

\section{Acknowledgements}

The authors sincerely acknowledge Danilo Malferrari and Daniele Fabbri (University of Bologna, Italy) for providing a calibrated solution containing anhydrosugars for calibration purposes.

The authors thank Eric Martin, Jérémy Valette, Ghislaine Volle, Nathalie Troalen, Gaël Senecal (CIRAD), Martin Drobek and Didier Cot (IEM) for technical and administrative support.

A special acknowledgement is given to Aurélien Renard (LPCME) and Jean Yves Baliteau (SADEF) for XPS and ICP-MS analyses.

The authors warmly thank Bruno Gagnepain (ADEME) and Claude Mirodatos (IRCELyon) for their scientific advices.

The authors thank both the CIRAD and the ADEME for financial support.

\section{References}

[1] A.V. Bridgwater, Review of fast pyrolysis of biomass and product upgrading, Biomass Bioenergy 38 (2012) 68-94.

[2] R. French, S. Czernik, Catalytic pyrolysis of biomass for biofuels production, Fuel Process. Technol. 91 (1) (2010) 25-32.

[3] M.C. Samolada, A. Papafotica, I.A. Vasalos, Catalyst evaluation for catalytic biomass pyrolysis, Energy Fuels 14 (6) (2000) 1161-1167.

[4] M.S. Abu Bakar, J.O. Titiloye, Catalytic pyrolysis of rice husk for bio-oil production, J. Anal. Appl. Pyrolysis 103 (0) (2013) 362-368.

[5] A. Aho, N. Kumar, K. Eränen, T. Salmi, M. Hupa, D.Y. Murzin, Catalytic pyrolysis of woody biomass in a fluidized bed reactor: influence of the zeolite structure Fuel 87 (12) (2008) 2493-2501.

[6] Y. Richardson, J. Blin, G. Volle, J. Motuzas, A. Julbe, In situ generation of Ni metal nanoparticles as catalyst for $\mathrm{H}_{2}$-rich syngas production from biomass gasification, Appl. Catal. A: Gen. 382 (2) (2010) 220-230

[7] R. Font, A. Marcilla, E. Verdu, J. Devesa, Catalytic pyrolysis of almonds shells: influence of temperature and $\mathrm{CoCl}_{2}$ almond shell ratio, Can. J. Chem. Eng. 68 (1990) 312-318.

[8] E. Auer, A. Freund, J. Pietsch, T. Tacke, Carbons as supports for industrial precious metal catalysts, Appl. Catal. A: Gen. 173 (2) (1998) 259-271.

[9] Q.A. Lu, C.Q. Dong, X.M. Zhang, H.Y. Tian, Y.P. Yang, X.F. Zhu, Selective fast pyrolysis of biomass impregnated with $\mathrm{ZnCl}_{2}$ to produce furfural: analytical Py-GC/MS study, J. Anal. Appl. Pyrolysis 90 (2) (2011) 204-212.

[10] E. Jakab, E. Mészáros, J. Borsa, Effect of slight chemical modification on the pyrolysis behavior of cellulose fibers, J. Anal. Appl. Pyrolysis 87 (1) (2010) $117-123$.

[11] J.A. Conesa, A. Marcilla, J.A. Caballero, Evolution of gases from the pyrolysis of modified almond shells: effects of impregnation with $\mathrm{CoCl}_{2}$, J. Anal. Appl. Pyrolysis 43 (1997) 59-69.

[12] A. Khelfa, A. Bensakhria, J.V. Weber, Investigations into the pyrolytic behaviour of birch wood and its main components: primary degradation mechanisms, additivity and metallic salt effects, J. Anal. Appl. Pyrolysis 101 (2013) 111-121.

[13] F.X. Collard, J. Blin, A. Bensakhria, J. Valette, Influence of impregnated metal on the pyrolysis conversion of biomass constituents, J. Anal. Appl. Pyrolysis 95 (2012) 213-226.

[14] C. Branca, C. Di Blasi, A. Galgano, Pyrolysis of corncobs catalyzed by zinc chloride for furfural production, Ind. Eng. Chem. Res. 49 (20) (2010) 9743-9752.

[15] C. Di Blasi, A. Galgano, C. Branca, Influences of the chemicals state of alkaline compounds and the nature of alkali metal on wood pyrolysis, Ind. Eng. Chem. Res. 48 (2009) 3359-3369.
[16] K. Bru, J. Blin, A. Julbe, G. Volle, Pyrolysis of metal impregnated biomass: an innovative catalytic way to produce gas fuel, J. Anal. Appl. Pyrolysis 78 (2) (2007) 291-300.

[17] O. Terakado, A. Amano, M. Hirasawa, Explosive degradation of woody biomass under the presence of metal nitrates, J. Anal. Appl. Pyrolysis 85 (1/2) (2009) 231-236.

[18] G. Dobele, G. Rossinskaja, T. Dizhbite, G. Telysheva, D. Meier, O. Faix, Application of catalysts for obtaining 1,6-anhydrosaccharides from cellulose and wood by fast pyrolysis, J. Anal. Appl. Pyrolysis 74 (1/2) (2005) 401-405.

[19] Z.A. Mayer, A. Apfelbacher, A. Hornung, Effect of sample preparation on the thermal degradation of metal-added biomass, J. Anal. Appl. Pyrolysis 94 (2012) $170-176$.

[20] M.V. Twigg, M.S. Spencer, Deactivation of supported copper metal catalysts for hydrogenation reactions, Appl. Catal. A: Gen. 212 (1/2) (2001) 161-174.

[21] R. van den Broek, L. Vleeshouwers, M. Hoogwijk, A. van Wijk, W. Turkenburg, The energy crop growth model SILVA: description and application to eucalyptus plantations in Nicaragua, Biomass Bioenergy 21 (5) (2001) 335-349.

[22] T. Buchholz, T. Tennigkeit, A. Weinreich, K. Windhorst, I. DaSilva, Modeling the profitability of power production from short-rotation woody crops in subSaharan Africa, Biomass Bioenergy 59 (0) (2013) 116-127.

[23] Y. Richardson, J. Motuzas, A. Julbe, G. Volle, J. Blin, Catalytic investigation of in-situ generated $\mathrm{Ni}$ metal nanoparticles for tar conversion during biomass pyrolysis, J. Phys. Chem. C 117 (2013) 23812-23831.

[24] J. Remón, F. Broust, J. Valette, Y. Chhiti, I. Alava, A.R. Fernandez-Akarregi, J. Arauzo, L. Garcia, Production of a hydrogen-rich gas from fast pyrolysis biooils: comparison between homogeneous and catalytic steam reforming routes, Int. J. Hydrogen Energy 39 (1) (2014) 171-182.

[25] C.A. Strydom, C.P.J. Van Vuuren, The thermal decomposition of cerium(III) nitrate, J. Therm. Anal. 32 (1987) 157-160.

[26] W. Brockner, C. Ehrhardt, M. Gjikaj, Thermal decomposition of nickel nitrate hexahydrate, $\mathrm{Ni}\left(\mathrm{NO}_{3}\right)_{2} \cdot 6 \mathrm{H}_{2} \mathrm{O}$, in comparison to $\mathrm{Co}\left(\mathrm{NO}_{3}\right)_{2} \cdot 6 \mathrm{H}_{2} \mathrm{O}$ and $\mathrm{Ca}\left(\mathrm{NO}_{3}\right)_{2} \cdot 4 \mathrm{H}_{2} \mathrm{O}$, Thermochim. Acta 456 (1) (2007) 64-68.

[27] C. Ehrhardt, M. Gjikaj, W. Brockner, Thermal decomposition of cobalt nitrato compounds: preparation of anhydrous cobalt(II)nitrate and its characterisation by infrared and Raman spectra, Thermochim. Acta 432 (1) (2005) 36-40.

[28] I.V. Morozov, K.O. Znamenkov, Y.M. Korenev, O.A. Shlyakhtin, Thermal decomposition of $\mathrm{Cu}\left(\mathrm{NO}_{3}\right)_{2} \cdot 3 \mathrm{H}_{2} \mathrm{O}$ at reduced pressures, Thermochim. Acta 403 (2) (2003) 173-179.

[29] R. Nikolic, S. Zec, V. Maksimovic, S. Mentus, Physico-chemical characterization of thermal decomposition course in zinc nitrate-copper nitrate hexahydrates, J. Therm. Anal. Calorim. 86 (2) (2006) 423-428.

[30] K. Wieczorek-Ciurowa, A.J. Kozak, The thermal decomposition of $\mathrm{Fe}\left(\mathrm{NO}_{3}\right)_{3} \cdot 9 \mathrm{H}_{2} \mathrm{O}$, J. Therm. Anal. Calorim. 58 (3) (1999) 647-651.

[31] M. Maneva, N. Petroff, The thermal dehydration, decomposition and kinetics of $\mathrm{Mn}\left(\mathrm{NO}_{3}\right)_{2} \cdot 6 \mathrm{H}_{2} \mathrm{O}$ and its deuterated analogue, J. Therm. Anal. $36(7 / 8)(1990)$ 2511-2520.

[32] A. Chin, D.S. Ellison, S.K. Poehlein, M.K. Ahn, Investigation of the decomposition mechanism and thermal stability of nitrocellulose/nitroglycerine based propellants by electron spin resonance, Propellants Explos. Pyrotech. 32 (2) (2007) 117-126.

[33] P. Serp, J.L. Figueiredo, Carbon Materials for Catalysis, John Wiley \& Sons, 2009 pp. 550.

[34] M. Jeguirim, V. Tschamber, J.F. Brilhac, P. Ehrburger, Interaction mechanism of $\mathrm{NO}_{2}$ with carbon black: effect of surface oxygen complexes, J. Anal. Appl. Pyrolysis 72 (1) (2004) 171-181.

[35] R. Bayerbach, D. Meier, Characterization of the water-insoluble fraction from fast pyrolysis liquids (pyrolytic lignin). Part IV: Structure elucidation of oligomeric molecules, J. Anal. Appl. Pyrolysis 85 (1/2) (2009) 98-107.

[36] R.H. Furneaux, J.M. Mason, I.J. Miller, A novel hydroxylactone from the Lewis acid-catalyzed pyrolysis of cellulose, J. Chem. Soc. Perkin Trans. 11 (1988) 49-51.

[37] X. Zhu, Q. Lu, Production of chemicals from selective fast pyrolysis of biomass, Biomass (2010) 147-164.

[38] D. Fabbri, C. Torri, V. Baravelli, Effect of zeolites and nanopowder metal oxides on the distribution of chiral anhydrosugars evolved from pyrolysis of cellulose: an analytical study, J. Anal. Appl. Pyrolysis 80 (1) (2007) 24-29.

[39] C. Di Blasi, C. Branca, A. Galgano, Products and global weight loss rates of wood decomposition catalyzed by zinc chloride, Energy Fuels 22 (1) (2008) 663-670.

[40] A.G. Marrani, F. Caprioli, A. Boccia, R. Zanoni, F. Decker, Electrochemically deposited ZnO films: an XPS study on the evolution of their surface hydroxide and defect composition upon thermal annealing, J. Solid State Electrochem. 18 (2) (2013) 505-513.

[41] M. Jeguirim, V. Tschamber, J.F. Brilhac, P. Ehrburger, Oxidation mechanism of carbon black by $\mathrm{NO}_{2}$ : effect of water vapour, Fuel 84(14/15)(2005) 1949-1956.

[42] J. Zawadzki, M. Wiśniewski, K. Skowrońska, Heterogeneous reactions of $\mathrm{NO}_{2}$ and NO-O $\mathrm{O}_{2}$ on the surface of carbons, Carbon 41 (2) (2003) 235-246.

[43] C.W. Klampfl, G. Breuer, C. Schwarzinger, B. Köll, Investigations on the effect of metal ions on the products obtained from the pyrolysis of cellulose, Acta Chim. Slov. 53 (2006) 437-443.

[44] F. X. Collard, J. Blin, A review on pyrolysis of biomass constituents: mechanisms and composition of the products obtained from the conversion of cellulose hemicelluloses and lignin, Renew. Sustain. Energy Rev. 38 (2014) 594-608. 